\title{
EVALUASI PENGENDALIAN SISTEM INFORMASI PENGIRIMAN PADA TL
}

\author{
Nelly; Liu Susiana; Wenni Kialiawati; Meiry; Anderes Gui \\ Jurusan Komputer Akuntansi, Fakultas Ilmu Komputer, Binus University \\ Jl. KH. Syahdan No. 9, Palmerah, Jakarta Barat 11480. \\ nelly@binus.edu
}

\begin{abstract}
The purpose of this study is to evaluate the control systems on the TL shipping information, in order to discern weaknesses or problems in delivery of enterprise information systems control using CobIT approach. The research method used is the data collecting by observation, checklists, interviews, and literature study. The results achieved are findings and issue recommendations that provide an illustration about a control of the running information delivery systems. From the illustration it is known that on the company's control of information delivery system, there are still many things that have not been up to standard. The conclusion obtained is that the control of information delivery systems that have been implemented meets only partially the standards set small, so it still needs much improvement.
\end{abstract}

Keywords: evaluation, information system control, delivery.

\begin{abstract}
ABSTRAK
Tujuan penelitian ini adalah melakukan evaluasi pengendalian sistem informasi pengiriman pada TL, sehingga dapat mengetahui kelemahan atau permasalahan yang terdapat pada pengendalian sistem informasi pengiriman perusahaan menggunakan pendekatan CobIT. Metode penelitian yang digunakan adalah pengumpulan data dengan observasi, checklist, wawancara, dan studi kepustakaan. Hasil yang dicapai adalah temuan masalah dan rekomendasi yang memberikan gambaran mengenai pengendalian sistem informasi pengiriman yang sedang berjalan. Dari gambaran tersebut diketahui bahwa pada pengendalian sistem informasi pengiriman perusahaan masih terdapat banyak hal yang belum sesuai dengan standar. Simpulan yang didapat adalah bahwa pengendalian sistem informasi pengiriman yang telah diterapkan hanya memenuhi sebagian kecil standar yang telah ditentukan, sehingga masih memerlukan banyak perbaikan.
\end{abstract}

Kata kunci: evaluasi, pengendalian sistem informasi, pengiriman 


\section{PENDAHULUAN}

Persaingan bisnis yang semakin ketat, menuntut perusahaan untuk menggunakan kemampuannya semaksimal mungkin agar dapat tetap eksis dalam persaingan tersebut. Hal ini dapat dicapai dengan peningkatan kinerja yang memerlukan evaluasi kinerja. Evaluasi kinerja yang berupa evaluasi sistem informasi dapat mengacu pada standar CobIT dan menggunakan Balanced Scorecard sebagai alat pengukuran kinerja yang berperan penting dalam menentukan keberhasilan proyek sistem informasi. TL merupakan perusahaan jasa pengiriman berbasis sistem informasi, sehingga evaluasi pengendalian sistem informasi merupakan hal yang penting bagi perusahan. Oleh karena itu, penulis memutuskan untuk melakukan "Evaluasi Pengendalian Sistem Informasi Pengiriman pada TL" untuk mengetahui kualitas pengendalian sistem informasi pengiriman perusahaan dan dapat ditingkatkan oleh perusahaan untuk mendukung pencapaian tujuan bisnis perusahaan.

\section{Tentang Perusahaan}

TL yang berlokasi di Jl. Penjernihan II no. 3B, Jakarta merupakan anak perusahaan dari Grup Transtama Antar Buana Inc. yang berdiri sejak tahun 1997 dengan komitmen menyediakan layanan angkutan domestik darat, laut dan udara terbaik. TL merupakan anggota dari Certified Transportation Network (CTN), Multimodal Transportation Group (MTG), IATA, ICAC, FIATA dan ASPERINDO. Di dukung oleh tenaga kerja muda, energik, profesional dan berpengalaman, TL telah memiliki jaringan 132 negara di seluruh dunia dan 33 provinsi nasional. Dilengkapi dengan sistem teknologi informasi yang kuat (e-warehouse \& $e$-distribution), TL terus menjadi perusahaan yang inovatif dalam rangka memberikan solusi terbaik bagi kebutuhan klien.

Proses bisnis TL berawal dari Customer yang melakukan pemesanan pengiriman barang ke Customer Service, kemudian Customer Service memberikan informasi pengangkutan barang ke Operational. Operational memesan muatan udara ke pihak bandara dan membuat STP (Surat Tanda Pengiriman), kemudian dilakukan pengangkutan barang, penimbangan, serta pengemasan barang. Setelah itu Operational membuat Surat Muatan Udara (SMU) berdasarkan STP, daftar tarif pengiriman pihak perusahaan, serta hasil booking muatan udara yang dikirim ke Customer Service. Customer Service membuat Way Bill berdasarkan STP, SMU, Ms_Customer, serta daftar tarif pengiriman pihak Customer. Operational mengirim barang ke bandara, beserta dengan STP dan SMU, kemudian memastikan barang tersebut telah diberangkatkan oleh pihak bandara, setelah itu menandatangani STP rangkap keempat yang dikirim ke Customer Service sebagai tanda barang telah diberangkatkan ke bandara tujuan.

Berdasarkan STP, SMU, serta Way Bill, Customer Service membuat SR (Shipment Request) yang terdiri dari dua bagian, yaitu shipment information (SI) dan shipment request (SR), Operational mengecek keberadaan barang dan meneruskan informasi keberadaan barang tersebut ke Customer Service, yang kemudian akan dibuat menjadi Prove of Delivery (POD). Finance membuat Invoice berdasarkan Ms_Customer dan Way Bill, dan membuat FP (Faktur Pajak), kemudian mengirimkannya untuk penagihan. Customer menerima tagihan dan melakukan pembayaran, kemudian Finance membuat Voucher Bukti Pembayaran (VBP) berdasarkan pembayaran yang telah diterima dan Invoice. Finance juga membuat Tanda Terima (TT) berdasarkan VBP dan Invoice.

\section{Ruang Lingkup}

Ruang lingkup pembatasan masalah dalam evaluasi pengendalian sistem informasi pengiriman pada TL yaitu: (1) Menganalisis dan mengevaluasi pengendalian sistem informasi pengiriman domestik dalam lingkup Door to Port (udara) pada TL; (2) Standar evaluasi yang digunakan adalah 
standar CobIT 4.1; (3) Perspective IT Balance Scorecard CobIT 4.1 yang digunakan adalah perspektif internal.

\section{Tujuan}

Tujuan dari penulisan paper ini adalah untuk: (1) Mengidentifikasi masalah pada pengendalian sistem informasi pengiriman TL untuk mengetahui kelebihan dan kelemahannya; (2) Membuat rekomendasi untuk perbaikan; (3) Memastikan apakah pengendalian sistem informasi pengiriman perusahaan telah memenuhi standar yang telah ditetapkan.

\section{Tinjauan Pustaka}

Evaluasi menurut Umar (2005, p36) adalah "Suatu proses untuk menyediakan informasi tentang sejauh mana suatu kegiatan tertentu telah dicapai, bagaimana perbedaan pencapaian itu dengan suatu standar tertentu untuk mengetahui apakah ada selisih diantara keduanya, serta bagaimana manfaat yang telah dikerjakan itu bila dibandingkan dengan harapan-harapan yang ingin diperoleh.” Audit sistem informasi menurut Gondodiyoto (2007, p.443), dimaksudkan untuk mengevaluasi tingkat kesesuaian antara sistem informasi dengan prosedur bisnis (business processes) perusahaan, kebutuhan pengguna (user needs), untuk mengetahui apakah suatu sistem informasi telah didesain dan diimplementasikan secara efektif, efisien dan ekonomis, memiliki mekanisme kepengamanan aset, serta menjamin integritas data yang memadai. CobIT menurut Gondodiyoto (2007, p.274) merupakan a set of best practices (framework) bagi pengelolaan teknologi informasi (IT management). CobIT adalah sekumpulan best practices untuk IT Governance yang dapat membantu auditor, pengguna (user) dan manajemen, untuk menjembatani gap antara resiko bisnis, kebutuhan kontrol dan masalah-masalah teknis TI. CobIT mempunyai empat domain yaitu: Plan and Organize, Acquire and Implement, Deliver and Support, Monitor and Evaluate. Pengiriman menurut Yunarto (2006, p.42) mengenal tiga komponen utama, yaitu intermediary (perantara), agent (agen), dan facilitator (fasilitator). Pengiriman merupakan suatu rangkaian kegiatan arus barang yang saling berhubungan dari produk ke perantara dan akhirnya ke tujuan akhir. Istilah-istilah penting terkait pengiriman menurut McLeod (2001) yaitu: shipment, shipping instruction, shipper, consignee, agent, notify party, airway bill, bill of lading, tracking, invoice.

\section{METODE}

Untuk memperoleh data teori penunjang yang lengkap dan akurat dalam penyusunan proyek ini, penulis menggunakan metode sebagai berikut: (1) riset kepustakaan; (2) penelitian lapangan berupa observasi, checklist, dan wawancara.

\section{HASIL DAN PEMBAHASAN}

Melalui penelitian lapangan, diperoleh 30 temuan. Berdasarkan temuan-temuan tersebut, penulis mencoba memberikan rekomendasi untuk kemajuan perusahaan (Tabel 1).

Tabel 1

Temuan dan Rekomendasi untuk TL

\begin{tabular}{lll}
\hline No. & \multicolumn{1}{c}{ Temuan } & \multicolumn{1}{c}{ Rekomendasi } \\
\hline 1. & $\begin{array}{l}\text { Perusahaan telah menentukan nilai } \\
\text { dari pengelolaan, membuat rencana } \\
\text { strategis dan taktis, menilai kinerja }\end{array}$ & $\begin{array}{l}\text { Sebaiknya perusahaan mengelola portfolio TI untuk menyempurnakan rencana } \\
\text { strategis TI yang penting dalam pengelolaan TI. }\end{array}$
\end{tabular}


TI dan menjajarkan TI dengan bisnis.

2. Perusahaan belum menetapkan arsitektur informasi.

3. Perusahaan belum menentukan arah teknologi.

4. Perusahaan telah memiliki kesesuaian tugas, menetapkan kunci keberhasilan personil TI dan prosedur staf kontrak.

5. Perusahaan telah menetapkan dan memelihara kerangka kerja keuangan TI, penganggaran TI, manajemen biaya dan manfaat.

6. Perusahaan belum mengkomunikasikan tujuan dan arah manajemen TI.

7. Perusahaan belum mengelola sumber daya manusia TI.

8. Perusahaan belum mengelola proyek.

9. Perusahaan telah mengidentifikasi solusi yang terotomatisasi.

10. Perusahaan telah menetapkan konfigurasi, mengimplementasikan, mengembangkan dan memelihara software.

11. Perusahaan belum memperoleh dan memelihara infrastruktur teknologi.

12. Perusahaan telah menjalankan operasi dan penggunaannya.

13. Perusahaan telah memilih supplier dan melakukan akuisisi sumber daya TI.

14. Perusahaan telah menetapkan prosedur dan standar, melaporkan status, dokumentasi dan penyelesaian perubahan.

15. Perusahaan telah melakukan pelatihan staf, membuat rencana pengujian dan implementasi, konversi data dan sistem, pengujian, promosi untuk produksi dan review implementasi perubahan.

16. Perusahaan belum mengelola dan mengatur tingkat layanan.
Sebaiknya perusahan membuat model arsitektur informasi, menggunakan kamus data dan aturan sintaks, membuat skema pembagian data, dan mengatur integritas informasi untuk menetapkan arsitektur informasi agar perusahaan memiliki perencanaan yang baik dalam pengelolaan TI.

Sebaiknya perusahaan melakukan perencanaan arah teknologi dan infrastruktur, mengawasi aturan dan tren di masa depan, dan membentuk badan arsitektur TI agar arah teknologi perusahaan menjadi jelas.

Sebaiknya perusahaan membuat kerangka kerja TI, membentuk komite strategi dan pengendali TI, penempatan organisasional pada fungsi TI, membuat struktur organisasi TI, menetapkan peran dan tanggung jawab, pertanggung jawaban atas jaminan mutu TI, resiko, keamanan, pemenuhan aturan, menetapkan kepemilikan data dan sistem, menetapkan pengawasan, penerimaan staf, dan hubungan dalam organisasi agar proses, organisasi dan hubungan TI perusahaan menjadi jelas. Sebaiknya perusahaan menetapkan prioritas anggaran TI untuk menyempurnakan pengelolaan investasi TI yang dapat memaksimalkan hasil dari investasi TI.

Sebaiknya perusahaan mendefinisikan kebijakan dan lingkungan pengendalian, mengembangkan kerangka kerja pengendalian dan resiko TI, melakukan manajemen kebijakan TI, melaksanakan kebijakan, standar, dan prosedur yang berlaku, menetapkan arah dan tujuan TI agar arah dan tujuan manajemen terkomunikasikan dengan baik.

Sebaiknya perusahaan melakukan perekrutan dan retensi personil, menetapkan kompetensi, pelatihan, tingkat kepercayaan pada personil, pemeriksaan latar belakang, evaluasi kinerja, dan menetapkan prosedur perubahan jabatan atau pemberhentian staf agar SDM TI dapat terkelola dengan baik.

Sebaiknya perusahaan membuat kerangka kerja manajemen program dan proyek, pendekatan manajemen proyek, komitmen dengan stakeholder, pernyataan ruang lingkup dan tahap permulaan proyek, rencana proyek yang terintegrasi, rencana kualitas proyek, menetapkan sumber daya proyek, melakukan manajemen resiko proyek agar proyek dapat terkelola dengan baik.

Sebaiknya perusahaan mempertahankan hal ini agar saat terjadi masalah, maka dapat ditangani dengan cepat dan tepat.

Sebaiknya perusahaan membuat desain tingkat tinggi, rinci, menetapkan pengendalian dan auditabilitas, keamanan dan ketersediaan software aplikasi, mengembangkan jaminan mutu software, membuat manajemen kebutuhan aplikasi agar proses dalam memperoleh dan memelihara software aplikasi berjalan dengan lancar.

Sebaiknya perusahaan membuat rencana akuisisi infrastruktur teknologi, menetapkan implementasi perlindungan dan ketersediaan sumber daya infrastruktur, memelihara infrastruktur, dan lingkungan pengujian kelayakan proses dalam memperoleh dan memelihara infrastruktur berjalan dengan lancar.

Sebaiknya perusahaan mempertahankan hal ini agar operasi dapat berjalan dengan efektif dan efisien.

Sebaiknya perusahaan melakukan pengendalian pengadaan dan manajemen kontrak dengan supplier agar pengadaan sumber daya TI dapat terealisasikan dengan baik.

Sebaiknya perusahaan menilai pengaruh, prioritas, dan otorisasi perubahan, serta membuat tindakan perubahan darurat agar perubahan dapat diterima dengan lebih baik lagi.

Sebaiknya perusahaan membuat rencana implementasi, membangun lingkungan pengendalian, melakukan konversi data dan sistem, melakukan pengujian penerimaan akhir perubahan agar perubahan dapat diinstalasi dan diakreditasi dengan lebih baik.

Sebaiknya perusahaan membuat kerangka kerja tingkat layanan, mendefinisikan layanan dari TI, membuat SLAs dan OLAs, mengawasi dan melaporkan tingkat pencapaian layanan, meninjau persetujuan dan perjanjian tingkat layanan agar dapat memberikan layanan yang memuaskan. 
17. Perusahaan telah melakukan perencanaan untuk meninjau kinerja dan kapasitas TI, untuk kedepannya juga, memastikan ketersediaan sumber daya TI.

18. Perusahaan telah membuat dan memelihara rencana, review, mengembangkan kerangka kerja, menguji, melatih dan

mendistribusikan layanan berkelanjutan TI.

19. Perusahaan telah mengelola akun user, melindungi sistem, mencegah, menyelidiki, memperbaiki ancaman sistem dan melindungi jaringan sistem.

20. Perusahaan telah mendefinisikan biaya layanan TI.

21. Perusahaan belum mendidik dan melatih para pengguna.

22. Perusahaan telah mengelola pertanyaan dari pelanggan.

23. Perusahaan belum mengelola konfigurasi.

24. Perusahaan telah menetapkan kebutuhan bisnis untuk pengelolaan dan pembagian data.

25. Perusahaan telah menyeleksi lokasi penempatan peralatan TI dan mengelola fasilitas.

26. Perusahaan telah menetapkan prosedur dan perintah operasi, membuat jadwal kerja dan melindungi dokumen rahasia.

27. Perusahaan menilai, melaporkan, dan memperbaiki kinerja TI.

28. Perusahaan belum mengawasi dan mengevaluasi pengendalian internal.

29. Perusahaan belum memastikan pemenuhan peraturan.

30. Perusahaan belum menyediakan pengelolaan TI.
Sebaiknya perusahaan meningkatkan kinerja dan kapasitas TI, serta mengawasi dan melaporkannya agar kinerja dan kapasitas TI dapat lebih ditingkatkan lagi.

Sebaiknya perusahaan melakukan pengujian, pelatihan, distribusi rencana kelanjutan TI, menetapkan penyimpanan cadangan agar layanan TI dapat berlangsung untuk jangka panjang.

Sebaiknya perusahaan melakukan manajemen dan perencanaan keamanan TI, mengelola identitas, melakukan pengujian, pengamatan, dan pengawasan keamanan, mendefinisikan insiden keamanan, mengelola kunci cryptographic, pengendalian pertukaran data rahasia agar keamanan sistem terjamin.

Sebaiknya perusahaan menghitung biaya TI, membuat model biaya TI dan pemeliharaannya agar pengalokasian biaya TI dapat dilakukan dengan tepat.

Sebaiknya perusahaan mengidentifikasi kebutuhan pendidikan dan pelatihan, malaksanakan pendidikan dan pelatihan, evaluasi manfaat dari pelatihan agar pelatihan yang dilaksanakan dapat memberikan hasil yang maksimal.

Sebaiknya perusahaan meningkatkan fungsi layanan, meningkatkan dan menutup kejadian layanan, menganalisa laporan aktivitas layanan agar dapat memuaskan pelanggan.

Sebaiknya perusahaan mengawasi penyimpanan konfigurasi, mengidentifikasi dan memelihara hal konfigurasi, meninjau kembali integritas konfigurasi agar konfigurasi dapat terkelola dengan baik.

Sebaiknya perusahaan menetapkan retensi dan penyimpanan data, sistem manajemen perpustakaan media, membuat back up dan restorasi data, syarat keamanan untuk manajemen data agar data tidak hilang atau rusak.

Sebaiknya perusahaan mengukur keamanan dan akses TI, memberikan perlindungan terhadap faktor lingkungan yang mengancam keamanan.

Sebaiknya perusahaan mengawasi infrastruktur TI dan melakukan pemeliharaan preventif pada hardware agar pengoperasian sistem dapat berjalan dengan baik.

Sebaiknya perusahaan membuat pendekatan pengawasan, mengumpulkan dan mendefinisi data pengawasan, membuat metode pengawasan kinerja agar pengawasan dan evaluasi kinerja dapat berjalan dengan efektif.

Sebaiknya perusahaan perlu mengawasi kerangka kerja pengendalian internal, meninjau kembali kepengawasan, menganalisa pengecualian pengendalian, penilaian pengendalian, memastikan adanya jaminan pengendalian internal, pengendalian internal pada pihak ketiga agar perusahaan memiliki pengendalian internal yang baik.

Sebaiknya perusahaan mengidentifikasi kebutuhan pemenuhan hukum, aturan, kontrak, optimis dalam menjawab kebutuhan eksternal, mengevaluasi pemenuhan kebutuhan eksternal, jaminan positif atas pemenuhan, pelaporan yang terintegrasi agar peraturan yang telah dibuat dipatuhi.

Sebaiknya perusahaan membentuk kerangka kerja pengelolaan TI, menetapkan penjajaran strategi, mendistribusikan nilai, mengelola sumber daya dan resiko, mengukur kinerja, menjamin kebebasan terkait konfirmasi tentang peraturan penggunaan TI agar dapat terkelola dengan baik.

\section{PENUTUP}

Berdasarkan hasil evaluasi pengendalian sistem informasi pengiriman pada TL yang mengacu pada standar CobIT dan menggunakan internal perspective, dapat disimpulkan bahwa pengendalian sistem pengiriman tersebut telah mengidentifikasi solusi yang terotomatisasi dan menjalankan operasi dan kegunaannya. Akan tetapi, proses-proses berikut ini belum terdapat pada pengendalian sistem 
pengiriman tersebut: (1) Menerapkan arsitektur informasi; (2) Menentukan arah teknologi; (3) Mengomunikasikan tujuan dan arah manajemen; (4) Mengelola sumber daya manusia TI; (5) Mengelola proyek; (6) Memperoleh dan memelihara infrastruktur teknologi; (7) Menetapkan dan mengatur tingkat layanan; (8) Mendidik dan melatih para pengguna; (9) Mengelola konfigurasi; (10) Mengawasi dan mengevaluasi pengendalian internal; (11) Memastikan pemenuhan peraturan dan menyediakan pengelolaan TI. Apabila dilihat secara keseluruhan, dapat disimpulkan bahwa masih terdapat banyak hal pada pengendalian sistem informasi pengiriman TL yang belum memenuhi standar yang telah ditentukan.

\section{DAFTAR PUSTAKA}

Gondodiyoto, S. (2007). Audit Sistem Informasi + Pendekatan CobIT, (edisi revisi). Jakarta: Mitra Wacana Media.

McLeod, Raymond Jr. (2001). Sistem Informasi Manajemen, (edisi ke-7). New Jersey: Prentice Hall International.

Umar, Husein.(2005). Evaluasi Kinerja Perusahaan: Teknik Evaluasi Bisnis dan Kinerja Perusahaan secara Komprehensif, Kuantitatif dan Modern. Jakarta: Gramedia Pustaka Utama.

Yunarto, Icun, Holly. (2006). In Sales and Distribution Management. Jakarta: Elex Media Komputindo. 